doi: 10.32620/oikit.2020.87.05

УДК 656.7.022.1

М.М.Орловський, А.В.Приймак, В.О.Хрістов*

\title{
Аналіз сучасного стану авіаційних перевезень в Україні
}

\author{
Національний аерокосмічний університет ім. М.Є. Жуковського \\ «Харківський авіаційний інститут» \\ * Харківський національний університет Повітряних Сил ім.І.Кожедуба
}

Розглянуто тенденції розвитку авіаційних перевезень в Україні в період світової глобалізації та лібералізації на ринку повітряних перевезень. Проведений аналіз вітчизняних авіаперевезень показав, що темпи зростання обсягу авіаперевезень в українському сегменті ринку, незважаючи на нестабільність військо-політичної та економічної ситуації в країні, $\epsilon$ оптимістичними для прогнозування майбутнього розвитку авіаційних перевезень в Україні. Ріст основних показників роботи цивільної авіацій України демонструє зростаючу зацікавленість учасників ринку до авіаційних перевезень. Ринок пасажирських авіаційних перевезень України має достатні передумови для свого успішного розвитку. Насамперед це обумовлене значним зростанням обсягів пасажирських перевезень авіаційним транспортом, створенням нових авіакомпаній в Україні, а саме авіакомпаній типу лоукост, входженням в авіаційний простір України нових іноземних авіакомпаній, відкриттям нових повітряних ліній українських перевізниками, схваленням безвізового режиму з країнами ЄС, модернізацією наявної інфраструктури аеропортів та їх розвитку з урахуванням сучасних вимог. Представлені основні виробничі показники та проведений аналіз пасажиро потоку. Визначено, що розвиток цивільної авіації пов'язаний із загальними тенденціями міжнародного повітряного транспорту і обумовлений як загальносвітовими, так і внутрішньодержавними соціально-економічними, політичними та іншими факторами. Визначено основні напрямки діяльності галузі на третя десятиріччя 21 століття.

Ключові слова: цивільна авіація, авіакомпанія, авіаперевезення, повітряне судно, аеропорти, пасажиропотік, стратегія розвитку.

\section{Постановка проблеми}

Цивільна авіація - один із найбільш важливих елементів транспортної інфраструктури будь-якої держави. Ї̈̈ розвиток $є$ пріоритетним напрямком розвитку усієї транспортної системи країни.

З урахуванням сучасних тенденцій світової глобалізації, особливостей географрічного положення України як «сполучного мосту» між Європою та Азією для вітчизняного авіаційного транспорту є перспективи подальшого розвитку та зміцнення позицій у світовій системі повітряних перевезень.

Крім того, Україна належить до небагатьох країн світу, що володіють повним циклом (макротехнологією) створення авіаційної техніки, і займає провідне місце на світовому ринку в секторі транспортної та регіональної пасажирської авіації. За рівнем розвитку літакобудування Україна належить до найбільш розвинутих держав. Великі досягнення у проектуванні авіаційних конструкцій належать кафедрі проектування літаків та вертольотів Національного аерокосмічного університету ім. М.Є. Жуковського «XAІ») [1,2].

\section{Основний матеріал статті}

Упродовж 2019 року пасажирські та вантажні перевезення здійснювали 29 вітчизняних авіакомпаній, якими загалом виконано 103,3 тис. комерційних рейсів (за 2018 рік - 100,2 тис. рейсів) [3]. 
У 2019 році ринок пасажирських авіаперевезень продовжував демонструвати позитивну динаміку. За статистичними даними кількість пасажирів, що скористались послугами українських авіакомпаній, збільшилась на 9,4 відсотка та склала 13705,8 тис. чоловік (Таблиця 1). Пасажирські перевезення протягом року здійснювали 18 вітчизняних авіаперевізників, серед яких найбільші обсяги виконано авіакомпаніями «Міжнародні авіалінії України», «Азур Ейр Україна», «Скайап», «Роза вітрів» та «Буковина». За звітний рік п'ятьма провідними авіакомпаніями загалом перевезено 13306,7 тис. осіб, що на 22,4 відсотка більше, ніж за 2018 рік та складає 97 відсотків від загальних обсягів пасажирських перевезень українських авіакомпаній.

Таблиця 1

Діяльність українських авіакомпаній та аеропортів

\begin{tabular}{|c|c|c|c|c|c|c|c|}
\hline & \multirow[b]{2}{*}{$\begin{array}{l}\text { Одиниці } \\
\text { виміру }\end{array}$} & \multicolumn{3}{|c|}{ Всього } & \multicolumn{3}{|c|}{ у т. ч. міжнародні } \\
\hline & & 2018 & 2019 & $\begin{array}{c}\% \\
19 / 18\end{array}$ & 2018 & 2019 & $\begin{array}{c}\% \\
19 / 18\end{array}$ \\
\hline \multicolumn{8}{|c|}{ Діяльність авіакомпаній } \\
\hline Перевезено пасажирів & тис.осіб & 12533,4 & 13705,8 & 109,4 & 11450,5 & 12547,2 & 109,6 \\
\hline в т.ч. на регулярних лініях &,,-- & 7867,5 & 8252,4 & 104,9 & 6796,1 & 7107,2 & 104,6 \\
\hline Виконані пасажиро-кілометри & млрд.пас.км & 25,9 & 30,2 & 116,6 & 25,4 & 29,7 & 116,9 \\
\hline в т.ч. на регулярних лініях & $-y^{-}$ & 15,6 & 17,4 & 111,5 & 15,1 & 16,9 & 111,9 \\
\hline $\begin{array}{l}\text { Перевезено вантажів та } \\
\text { пошти }\end{array}$ & тис.тонн & 99,1 & 92,6 & 93,4 & 98,8 & 92,0 & 93,1 \\
\hline в т.ч. на регулярних лініях & $-{ }_{-\prime,}^{-}$ & 21,1 & 19,6 & 92,9 & 20,8 & 19,4 & 93,3 \\
\hline $\begin{array}{l}\text { Виконані тонно-кілометри } \\
\text { (вантажі+пошта) }\end{array}$ & млн.ткм & 339,7 & 295,6 & 87,0 & 339,6 & 295,2 & 86,9 \\
\hline в т.ч. на регулярних рейсах &,- & 92,0 & 93,0 & 101,1 & 91,9 & 92,9 & 101,1 \\
\hline Виконано комерційних рейсів & тис. & 100,2 & 103,3 & 103,1 & 84,0 & 86,7 & 103,2 \\
\hline в т.ч. регулярних &,-- & 67,0 & 66,6 & 99,4 & 52,3 & 51,6 & 98,7 \\
\hline \multicolumn{8}{|c|}{ Діяльність аеропортів } \\
\hline Відправлено та прибуло ПС & тис.од. & 182,8 & 201,2 & 110,1 & 145,6 & 162,7 & 111,7 \\
\hline в т.ч. на регулярних рейсах &,$-{ }^{-}$ & 140,3 & 153,6 & 109,5 & 111,5 & 124,9 & 112,0 \\
\hline Пасажиропотоки & тис.осіб & 20545,4 & 24334,5 & 118,4 & 18357,5 & 21994,1 & 119,8 \\
\hline в т.ч. на регулярних рейсах & $-y^{-}$ & 15811,1 & 18833,0 & 119,1 & 13658,7 & 16530,2 & 121,0 \\
\hline Поштовантажопотоки & тис.тонн & 56,4 & 60,2 & 106,7 & 55,2 & 58,4 & 105,8 \\
\hline в т.ч. на регулярних рейсах &,- & 51,3 & 54,1 & 105,5 & 50,1 & 53,0 & 105,8 \\
\hline
\end{tabular}

Більше половини (51,9 відсотка) всіх пасажирських перевезень вітчизняних авіакомпаній складають міжнародні регулярні перевезення.

За статистичними даними з загальної кількості пасажирів, що скористались послугами українських авіакомпаній (13705,8 тис. осіб) 12547,2 тис. осіб (більш на 8,7 відсотків ніж позаторік) перевезено на міжнародних лініях та 1158,6 тис. осіб (більш на 6,5 відсотків ніж позаторік) перевезено на внутрішніх лініях [4] (рис. 1).

У 2019 році міжнародні регулярні пасажирські перевезення відповідно до затвердженого розкладу руху здійснювали 10 вітчизняних авіакомпаній до 46 країн світу. Кількість пасажирів, які скористались послугами українських компаній, зросла на 4,6 відсотка та становила 7107,2 тис. осіб, при цьому середній ві- 
дсоток пасажирського завантаження міжнародних регулярних рейсів збільшився на 2,1\% та склав $80,9 \%$. Тривав розвиток мережі маршрутів вітчизняних авіаперевізників, якими розпочато експлуатацію на регулярній основі 17 міжнародних авіаліній. Водночас мало місце розширення діяльності на українському ринку іноземних авіакомпаній, послугами яких скористались 9422,5 тис. пасажирів, що на 37,4 відсотка перевищує показник 2018 року та складає 57 відсотків від загальних обсягів регулярних пасажирських перевезень між Україною та країнами світу. Загалом регулярні пасажирські перевезення до України виконували 40 іноземних авіакомпаній (у тому числі чотири нові - австрійська авіакомпанія «Laudamotion, фрранцузька «Aigle Azur» (здійснювала польоти до вересня 2019 року), ізраїльська «Israir Airlines» та норвезька «Scandinavian Airlines System») 3 37 країн світу. Протягом року іноземними авіаперевізниками було відкрито 29 нових маршрутів, з них 21 новий маршрут - авіакомпаніями «Ryanair» та «Wizz Air Hungary».

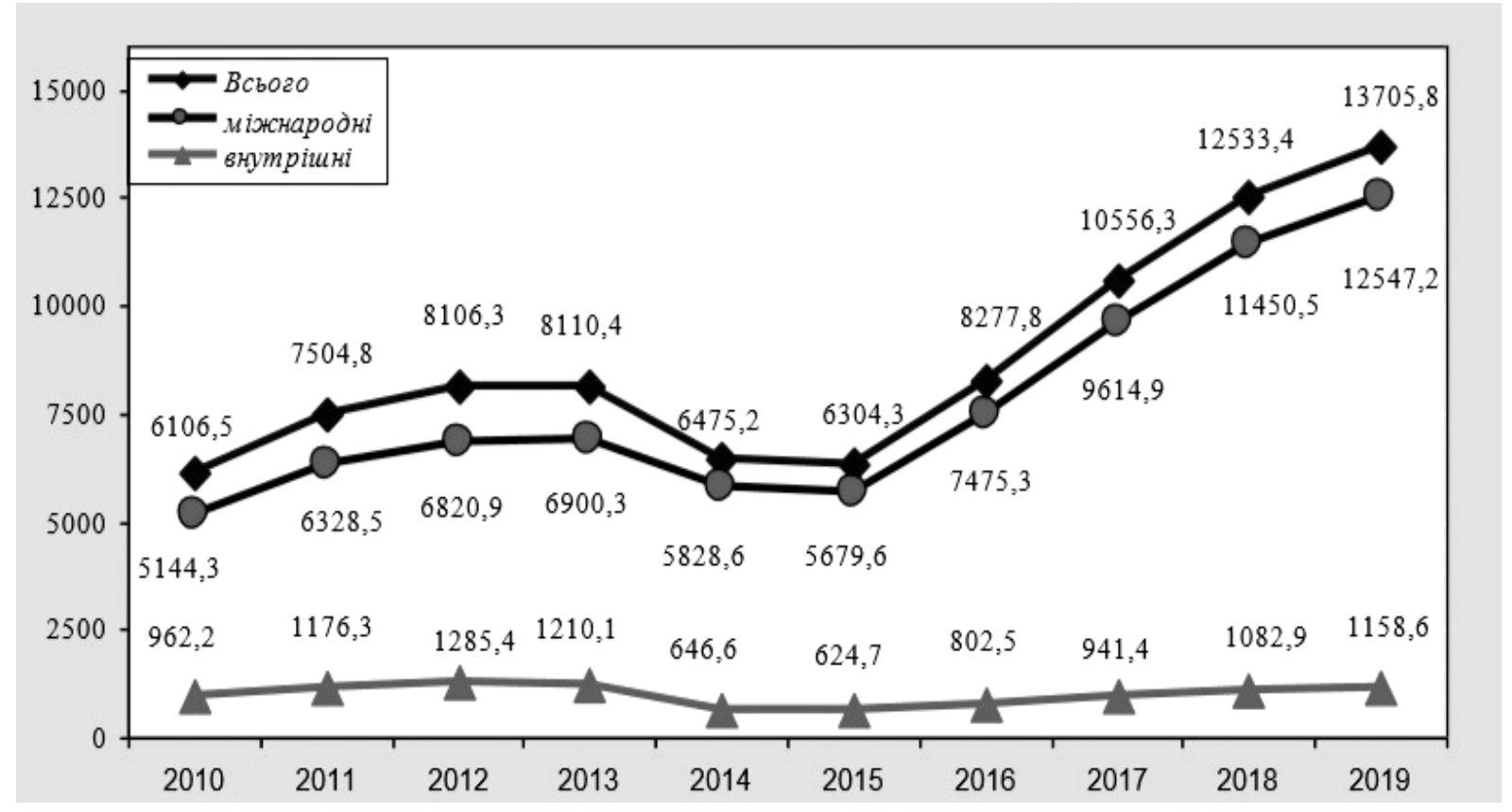

Рис. 1. Динаміка обсягів перевезень пасажирів авіаційним транспортом України, тисяч осіб

За підсумками 2019 року найбільший темп приросту (16,9 відсотка) кількості перевезених пасажирів вітчизняними авіакомпаніями спостерігався в такому сегменті ринку, як міжнародні польоти на нерегулярній основі. За рік 16-ма українськими авіакомпаніями перевезено 5440 тис. пасажирів. При цьому, майже 97 відсотків таких перевезень здійснено п'ятьма вищезгаданими провідними авіакомпаніями.

Регулярні внутрішні пасажирські перевезення між 11 містами України виконували чотири вітчизняні авіакомпанії («Міжнародні авіалінії України», «Мотор Січ», «Роза вітрів» та «Скайап»). Протягом 2019 року регулярними рейсами у межах України перевезено 1145,2 тис. пасажирів, що на 6,9 відсотка більше, ніж за попередній рік. При цьому, середній відсоток пасажирського завантаження внутрішніх регулярних рейсів українських авіакомпаній склав 75,9\% (проти 79,3 у 2018 році). 
За звітний рік обсяги перевезень вантажів та пошти авіаційним транспортом України скоротились на 6,6 відсотка та становили 92,6 тис. тонн. Перевезення вантажів та пошти виконували 20 вітчизняних авіакомпаній. Лідери вантажоперевезень - АТП ДП «Антонов», авіакомпанії «Міжнародні авіалінії України», «ЗетАвіа», «Максімус Еірлайнс» та «Южмашавіа». Зазначеними авіапідприємствами у звітному році було виконано майже 85 відсотків загальних обсягів перевезень вантажів та пошти. Слід зазначити, що більшу частину вантажоперевезень традиційно складали чартерні рейси в інших державах в рамках гуманітарних та миротворчих програм $\mathrm{OOH}$, а також згідно з контрактами та угодами з іншими замовниками.

Аналізуючи віковий стан авіапарку цивільних повітряних суден (ПС) України слід зазначити значну нерівномірність розподілу за роками випуску. $€$ можливість чіткого виділення двох характерних вікових груп авіаційної техніки, які відповідають різним умовам комплектування авіаційного парку цивільних ПС України (рис. 2) [5].

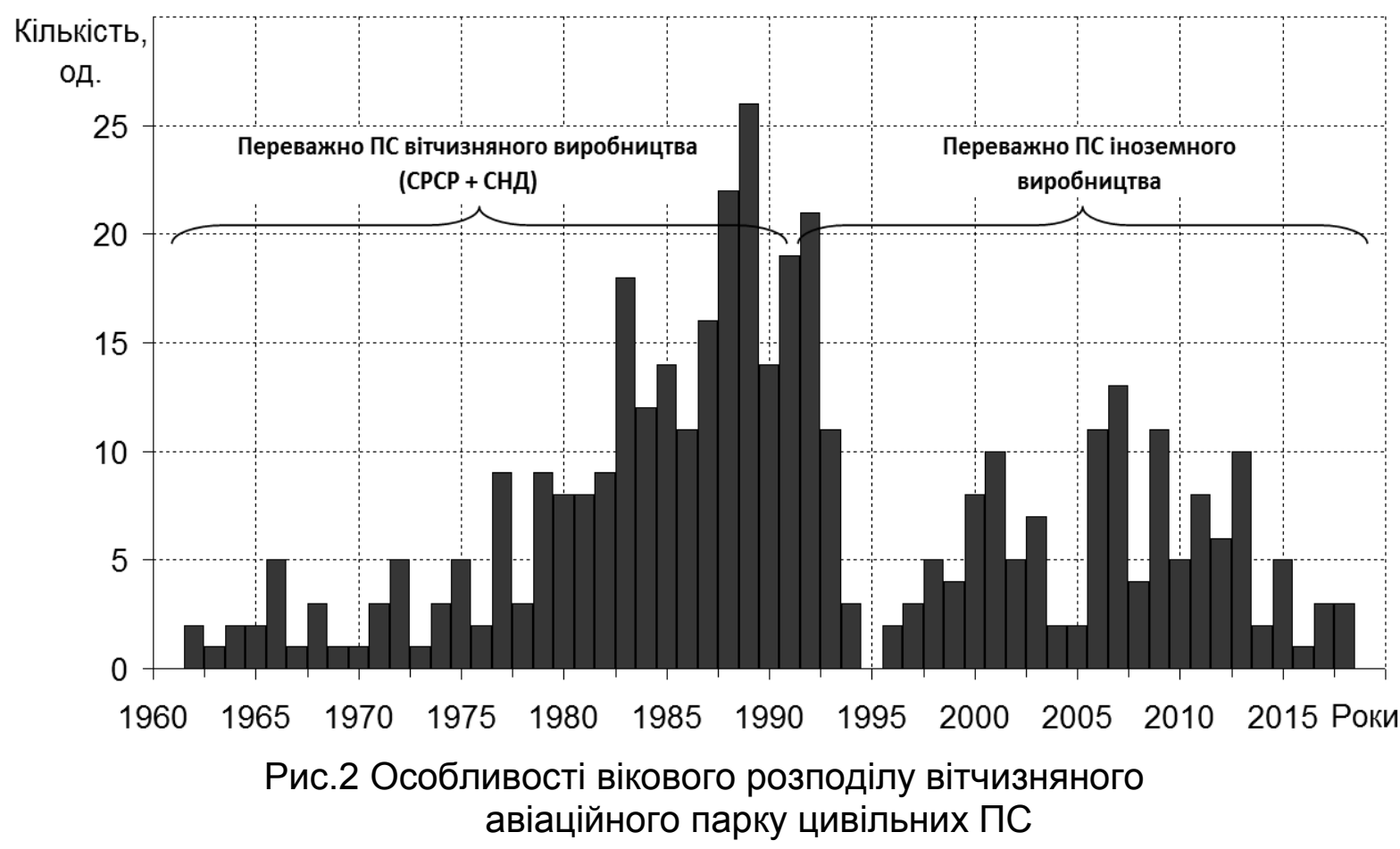

До першої групи, це $\approx 67 \%$ усіх проаналізованих ПС, відноситься авіаційна техніка, вік якої перевищує 25 років. Це техніка в більшості своїй виробництва СРСР та України. Частка ж іноземної техніки тут незначна й не перевищує 10\% ПС цієї групи.

До другої вікової групи, правий розподіл на рис.2 відносяться ПС переважно іноземного виробництва. Частка вітчизняної техніки тут незначна та складає близько 9\% (всього 11 ПС).

Переважна більшість ПС іноземного виробництва сконцентрована в таких авіакомпаніях, як: ПрАТ «Авіакомпанія «Міжнародні авіалінії України» (МАУ), ТОВ «Авіаційна компанія «Роза вітрів», ТОВ «ЯнЕір» ЛТД, ТОВ «Авіакомпанія «Азур Ейр Україна», ТОВ «Авіакомпанія Браво» та інших. Загалом, у перерахованих авіакомпаніях налічується 73 ПС типу Boeing, Airbus, Embraer, Hawker, 
DC-9, що становить 70\% усіх літаків іноземного виробництва, які зареєстровані та експлуатуються в Україні.

Інформація щодо структури та вікового складу деяких авіакомпаній України, на оснащенні яких знаходиться авіаційна техніка іноземного виробництва, представлена в таблиці 2.

Дійсно, більшість із наведених в таблиці компаній володіють досить скромними авіаційними парками, кількість ПС в яких становить 2-5 одиниць, що 3 урахуванням усіх витрат не дозволяє їм накопичувати та оперувати коштами, які $\epsilon$ необхідними для своєчасного оновлення своїх авіаційних парків.

Найбільш старими зразками авіаційної техніки, що активно використовуються українськими авіакомпаніями є літаки типу Ан-12, вік яких змінюється в межах від 46 до 56 років. Відносно молодими є літаки типів Ан-74 та Ан -124, середній вік яких становить 25 та 26,6 років відповідно (Таблиця 3).

Таблиця 2

Кількість іноземних ПС у деяких авіаперевізників України

\begin{tabular}{|c|c|c|c|}
\hline Авіакомпанія & Тип ПС & $\begin{array}{c}\text { Кількість } \\
\text { ПС } \\
\end{array}$ & $\begin{array}{c}\text { Середній вік } \\
\text { парку за типами }\end{array}$ \\
\hline СкайАп & Boeing 737-800 & 3 & 5 \\
\hline \multirow[t]{2}{*}{ Атласджет Україна } & Airbus A320-214 & 1 & 18 \\
\hline & Airbus 320-232 & 1 & 17 \\
\hline \multirow[t]{3}{*}{ Азур Ейр Україна } & Boeing 737-800 & 2 & 17 \\
\hline & Boeing 767-300 & 2 & 26 \\
\hline & Boeing 737-900ER & 1 & 11 \\
\hline \multirow[t]{3}{*}{ Bravo Airways } & Boeing 737-500 & 2 & 27 \\
\hline & DC-9-83 (MD-83) & 2 & 27 \\
\hline & DC-9-82 (MD-82) & 1 & 28 \\
\hline \multirow[t]{2}{*}{ Anda Air } & DC-9-83 (MD-83) & 2 & 28 \\
\hline & Airbus 319-114 & 1 & 22 \\
\hline Дрім Вінд & Боїнг 737-300 & 2 & 27,5 \\
\hline ПрАТ "Авіакомпанія "Буковина" & DC-9-82 (MD-82) & 3 & 28 \\
\hline \multirow[t]{4}{*}{ ТОВ "ЯнЕір" ЛТД } & Боїнг 737-300 & 2 & 28 \\
\hline & Боїнг 737-400 & 3 & 28,67 \\
\hline & Airbus A320-212 & 1 & 21 \\
\hline & Airbus 321-112 & 1 & 20 \\
\hline Всього & - & 30 & 22,8 \\
\hline
\end{tabular}

Загалом комерційні рейси вітчизняних та іноземних авіакомпаній у 2019 році обслуговували 19 українських аеропортів та аеродромів. Кількість відправ- 
лених та прибулих упродовж року повітряних суден склала 201,2 тис. (проти 182,8 тисяч за попередній рік). При цьому пасажиропотоки через аеропорти України зросли на 18,4 відсотка та досягли відмітки 24334,5 тис. осіб. Поштові вантажопотоки збільшились на 6,7 відсотка та склали 60,2 тис. тонн [6].

Таблиця 3

Кількість вітчизняних ПС та їхня характеристика за віком

\begin{tabular}{|c|c|c|c|c|}
\hline $\begin{array}{c}\text { № } \\
\text { п/п }\end{array}$ & $\begin{array}{c}\text { Тип ПС (без вказівки } \\
\text { модифікацій) }\end{array}$ & $\begin{array}{c}\text { Кількість } \\
\text { ПС }\end{array}$ & $\begin{array}{c}\text { Середній } \\
\text { вік, роки }\end{array}$ & $\begin{array}{c}\text { Вікове плече/ } \\
\text { (тіп-тах) роки }\end{array}$ \\
\hline 1. & Ан-12 & 19 & 51 & $10 / 46-56$ \\
\hline 2. & Ан-24 & 3 & 46 & $3 / 45-47$ \\
\hline 3. & Ан-26 & 18 & 36,9 & $11 / 33-44$ \\
\hline 4. & Ан-74 & 4 & 25 & $14 / 17-31$ \\
\hline 5. & Ан-124 & 8 & 26,6 & $17 / 15-32$ \\
\hline 6. & Ан-140 & 1 & 15 & - \\
\hline 7. & Ан-148 & 1 & 7 & - \\
\hline 8. & Ан-178 & 1 & 3 & $13 / 30-43$ \\
\hline 9. & Як-40/42 & 5 & 37,2 & $14 / 25-39$ \\
\hline 10. & Іл-76 & 37 & 28,5 & $14 / 16-30$ \\
\hline 11. & Ми-8 & 8 & 28,4 & $5 / 26-31$ \\
\hline 12. & Ка-32 & 123 & 33,4 & $41 / 15-56$ \\
\hline & Всього & & & 29,7 \\
\hline
\end{tabular}

Близько 98 відсотків пасажиропотоків та практично всі поштовантажопотоки сконцентровані в 7 основних аеропортах (Бориспіль, Київ (Жуляни), Львів, Одеса, Харків, Запоріжжя та Дніпропетровськ) (рис. 3).

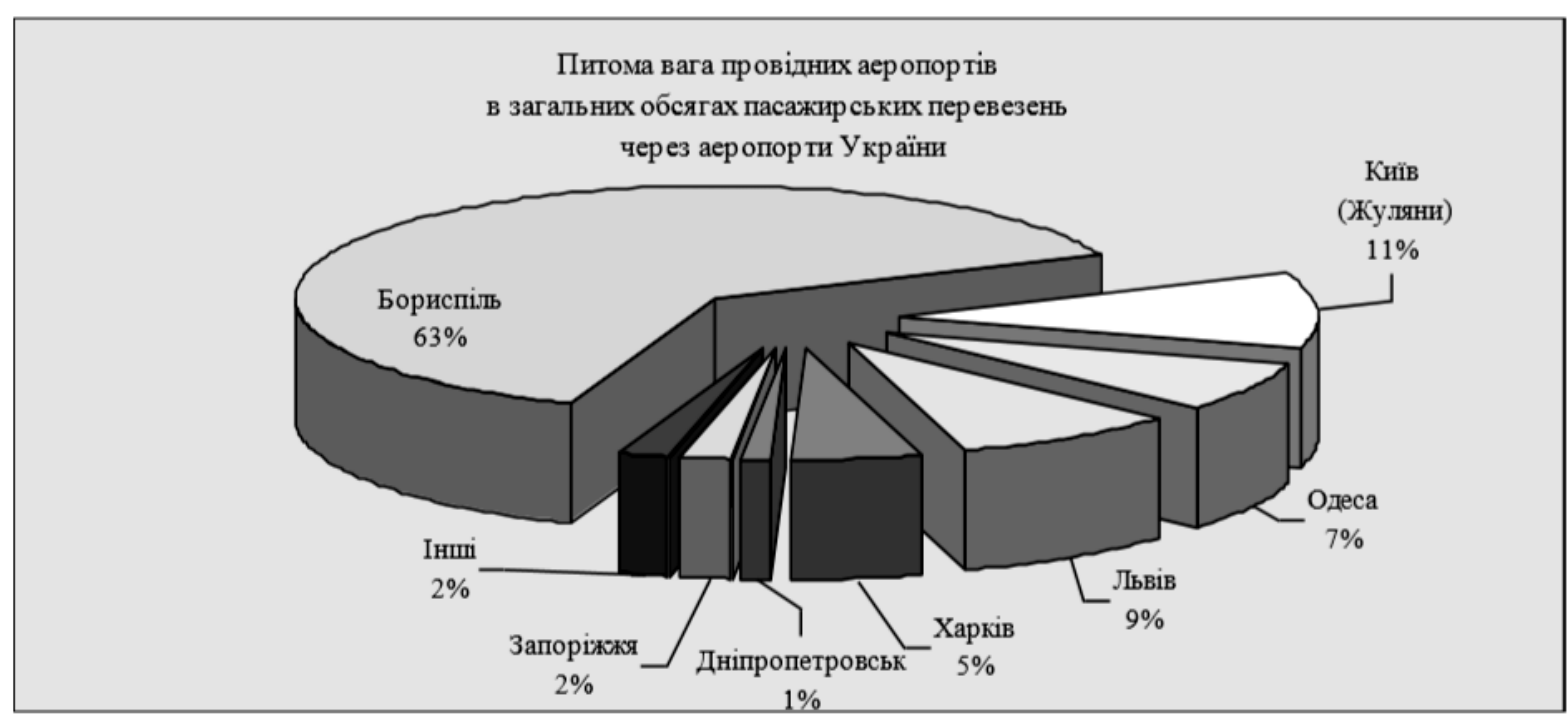

Рис. 3. Питома вага провідних аеропортів в загальних обсягах пасажирських перевезень через аеропорти України 
Зростання кількості обслугованих пасажирів порівняно з 2018 роком зафріксовано в наступних аеропортах: Харків - на 39,4 відсотка, Львів - на 38,8 відсотка, Бориспіль - на 21,1 відсотка, Дніпропетровськ - на 13,2 відсотка, Одеса - на 17,1 відсотка та Запоріжжя - на 8,4 відсотка. В той же час в столичному аеропорту Київ (Жуляни) мало місце скорочення пасажиропотоку (на 6,9 відсотка).

Державним підприємством обслуговування повітряного руху України (Украерорух) за звітний рік обслуговано 335,4 тисяч польотів проти 300,9 тисяч у 2018 році (зростання трафріку на 11,5\%), що становить 63\% від обсягів 2013 року. Третина обслуговуваних польотів виконувалась українськими авіакомпаніями. У 2019 році кількість обслугованих польотів, виконаних літаками та вертольотами авіакомпаній України, збільшилась на 2,9 відсотка, іноземними авіакомпаніями - на 16,2 відсотка [7].

Значну вагову частину зростання трафіку забезпечує розвиток міжнародних аеропортів України, обсяги внутрішньо трафріку та польотів з вильотом та посадкою у 2019 році перевищили рівень 2013 року на 6\%. Кількість польотів по 4-х маршрутах обслуговування повітряного руху, доступних для планування у повітряному просторі над відкритим морем, де відповідальність за обслуговування повітряного руху покладена на Україну міжнародними договорами, зросла на 2,4\% у порівнянні з 2018 роком.

Метою стратегії розвитку авіаційного транспорту та аеропортів України є формування в Україні системи законодавства авіатранспортної галузі на основі регламентів і директив Європейського Союзу, а також створення сприятливих організаційних, податкових, митних, інвестиційних та кредитно-грошових умов для зростання обсягів перевезень пасажирів, вантажів і пошти на внутрішньому та міжнародному ринках вітчизняними авіакомпаніями; організації нових робочих місць в авіатранспортній галузі та суміжних сфрерах; розширення географії повітряного сполучення України; реалізації авіаційного транзитного потенціалу України тощо [5, 8].

Україна є членом таких міжнародних авіаційних організацій як Європейська конференція цивільної авіації (ЄКЦА), Європейська організація з безпеки аеронавігації «Євроконтроль» (ЄВРОКОНТРОЛЬ) та Міжнародна організація цивільної авіації (ICAO) [9].

У липні 2019 року ICAO провела IVM (Integrated Validation Mission) в Україні з метою перевірки стану забезпечення впровадження Стандартів та Рекомендованої практики (SARPs) ICAO та дотримання зобов'язань, що випливають 3 участі України в ICAO у соері розслідування авіаційних подій та інцидентів (AIG) та ANS аеронавігаційного обслуговування (ANS). У результаті IVM рівень імплементації SARPs ICAO в Україні в сфрері ANS збільшився з 68.24\% до 78.24\%, в сорері AIG - з 50\% до 60\%. Для впровадження SARPs ICAO продовжувалась робота з опрацювання поправок та їх імплементації в нормативно-правову базу України. Зокрема вимоги 8 поправок увійшли до шести оновлених нормативноправових актів у галузі сертифікації повітряних суден та підтримання льотної придатності, обслуговування повітряного руху, метеорологічного забезпечення авіації, обслуговування аеронавігаційною інформацією та моніторингу викидів (емісіі).

У 2019 році продовжувалось вдосконаленню чинного законодавства України, у тому числі шляхом імплементації відповідних актів $€ С$ у вітчизняне законодавство. Було прийнято і затверджено 13 Авіаційних правил України, зокрема 
Авіаційні правила України «Правила повітряних перевезень та обслуговування пасажирів і багажу» [10].

\section{Висновки}

Сьогодні в Україні сформувалась достатньо ефективна та розвинута авіаційно-транспортна система, яка характеризується стабільно високими темпами розвитку, високим рівнем адаптивних можливостей до зміни фрактичних умов функціонування та стійкістю до кризових явищ, які виникають в соціальнополітичному та економічному житті країни.

Проведений аналіз вітчизняних авіаперевезень показав, що темпи зростання обсягу авіаперевезень в українському сегменті ринку, незважаючи на нестабільність військо-політичної та економічної ситуації в країні, є оптимістичними для прогнозування майбутнього розвитку авіаційних перевезень в Україні. Ріст основних показників роботи цивільної авіацій України демонструє зростаючу зацікавленість учасників ринку до авіаційних перевезень. Враховуючи вищесказане, можемо дійти висновку, що ринок пасажирських авіаційних перевезень України має достатні передумови для свого успішного розвитку. Насамперед це обумовлене значним зростанням обсягів пасажирських перевезень авіаційним транспортом, створенням нових авіакомпаній в Україні, а саме авіакомпаній типу лоукост, входженням в авіаційний простір України нових іноземних авіакомпаній, відкриттям нових повітряних ліній українських перевізниками, схваленням безвізового режиму з країнами $€$, модернізацією наявної інфраструктури аеропортів та їх розвитку з урахуванням сучасних вимог.

Крім того; сьогодні українське авіабудування має великий потенціал для подальшого інтенсивного розвитку.

Основними напрямками розвитку авіаційної галузі України на третя десятиріччя 21 століття повинно бути:

- Відродження власної авіабудівної галузі;

- Остаточна повна гармонізація законодавства України із законодавством Європейського Союзу;

- Міжнародне співробітництво;

- Лібералізація повітряного сполучення;

- Підвищення рівня безпеки авіації та авіаційної безпеки;

- Підвищення якості процесу організації авіаційних перевезень.

\section{Список літератури}

1. Гребеников, А.Г. Методология интегрированного проектирования и моделирования сборных самолетных конструкций [Текст]: монография / А.Г. Гребеников. - Харьков: Нац. аэрокосм. ун-т «ХАИ», 2006. - 532 с.

2. Интегрированное проектирование и моделирование высокоресурсных растянутых панелей крыла транспортного самолета [Текст]: монография / А.Г. Гребеников, Е.Т. Василевский, В.А. Матвиенко, А.М. Гуменный, С.П. Светличный. - Харьков: Нац. аэрокосм. ун-т им. Н.Е. Жуковского «Харьк. авиац. инт», 2011. - 192 c.

3. Статистичні дані в галузі авіатранспорту. Підсумки діяльності авіаційної галузі України за 2019 рік. Офіційний сайт Міністерства інфраструктури України [Електронний ресурс]. - Режим доступу: https://mtu.gov.ua/content/statistichni-dani-v-galuzi-aviatransportu.html. 
4. Державний комітет статистики України. Статистична інформація [Електронний ресурс]. - Режим доступу: http://www.ukrstat.gov.u

5. Орловський М.М. Дослідження стану льотної придатності та перспективи розвитку цивільного авіаційного парку України / М.М. Орловський, А.В. Приймак, Ю.Ю. Височанська, К.А. Гальчинський // Открытые информационные и компьютерные интегрированные технологии: сб.науч. тр. Нац. аэрокосм. ун-та им. Н. Е. Жуковского «ХАИ». - Вып. 83. - Х., 2019. - С. 42 - 58.

6. Total air traffic of passengers, by scope, type of flight and period / National Statistics Institute. - URL: http://www.ine.es/jaxi/tabla.do.

7. Офріційний сайт Міністерства інфрраструктури України [Електронний ресурс]. - Режим доступу: http://mtu.gov.ua.

8. Kharchenko, V., Illiashenko, O. Concepts of green IT engineering: Taxonomy, principles and implementation. Studies in Systems, Decision and Control. 2017. Vol. 74, pp. 3-19.

9. Повітряний кодекс України [Електронний ресурс]. - Режим доступу: https://zakon.rada.gov.ua/laws/show/3393-17

10. Авіаційні правила України. Правила повітряних перевезень та обслуговування пасажирів і багажу (наказ Державіаслужби від 26.11.2018 р. №1239) [Електронний ресурс]. - Режим доступу: https:// www.zakon.rada.gov.ua/laws/show/z0141-19

\section{References}

1. Grebenikov, A.G. Metodologija integrirovannogo proektirovanija i modeli-rovanija sbornyh samoletnyh konstrukcij [Tekst]: monografija / A.G. Grebenikov. - Har'kov: Nac. ajerokosm. un-t «HAl», 2006. - 532 s.

2. Integrirovannoe proektirovanie i modelirovanie vysokoresursnyh rastjanutyh panelej kryla transportnogo samoleta [Tekst]: monografija / A.G. Grebenikov, E.T. Vasilevskij, V.A. Matvienko, A.M. Gumennyj, S.P. Svetlichnyj. Har'kov: Nac. ajerokosm. un-t im. N.E. Zhukovskogo «Har'k. aviac. in-t», 2011. - 192 s.

3. Staty`sty`chni dani v galuzi aviatransportu. Pidsumky diyal’nosti aviacijnoyi galuzi Ukrayiny` za 2019 rik. Oficijny’j sajt Ministerstva infrastruktury Ukrayiny [Elektronny j resurs]. - Rezhy'm dostupu: https://mtu.gov.ua/content/statistichni-dani-v-galuzi-aviatransportu.html.

4. Derzhavny j komitet staty`sty`ky` Ukrayiny`. Staty`sty`chna informaciya [Elektronny`j resurs]. - Rezhy`m dostupu: http://www.ukrstat.gov.u

5. Orlovs ky`j M.M. Doslidzhennya stanu lotnoyi pry datnosti ta perspekty`vy` rozvy`tku cy`vil`nogo aviacijnogo parku Ukrayiny` / M.M. Orlovs`ky`j, A.V. Pry`jmak, Yu.Yu. Vy`sochans`ka, K.A. Gal’chy`ns`ky`j // Otkrыtыe y’nformacy’onnыe y’ komp 'yuternыe y’ntegry rovannыe texnology 'y”: sb.nauch. tr. Nacz. aэrokosm. un-ta y`m. N. E. Zhukovskogo "XAY`». - Vыp. 83. - X., 2019. - S. $42-58$.

6. Total air traffic of passengers, by scope, type of flight and period / National Statistics Institute. - URL: http://www.ine.es/jaxi/tabla.do

7. Oficijny j sajt Ministerstva infrastruktury` Ukrayiny` [Elektronny`j resurs]. - Rezhy`m dostupu:: http://mtu.gov.ua.

8. Kharchenko, V., Illiashenko, O. Concepts of green IT engineering: Taxonomy, principles and implementation. Studies in Systems, Decision and Control. 2017. Vol. 74, pp. 3-19. 
9. $\quad$ Povitryany`j kodeks Ukrayiny` [Elektronny`j resurs]. - Rezhy`m dostupu: https://zakon.rada.gov.ua/laws/show/3393-17

10. Aviacijni pravy`la Ukrayiny`. Pravy`la povitryany`x perevezen` ta obslugovuvannua pasazhy`riv i bagazhu (nakaz Derzhaviasluzhby` vid 26.11.2018 r. \#1239) [Elektronny j resurs]. - Rezhy'm dostupu:: https:// www.zakon.rada.gov.ua/laws/show/z0141-19

Надійшла до редакції 21.01.2020, розглянута на редколегії 22.01.2020.

\section{Анализ современного состояния авиационных перевозок в Украине}

Рассмотрены тенденции развития авиационных перевозок в Украине в период мировой глобализации и либерализации на рынке воздушных перевозок. Проведенный анализ отечественных авиаперевозок показал, что темпы роста объема авиаперевозок в украинском сегменте рынка, несмотря на нестабильность военно-политической и экономической ситуации в стране, являются оптимистичными для прогнозирования будущего развития авиационных перевозок в Украине. Рост основных показателей работы гражданской авиаций Украины демонстрирует растущую заинтересованность участников рынка в авиационных перевозках. Рынок пассажирских авиационных перевозок Украины имеет достаточные предпосылки для своего успешного развития. Прежде всего это обусловлено значительным ростом объемов пассажирских перевозок авиационным транспортом, созданием новых авиакомпаний в Украине, а именно авиакомпаний типа лоукост, вхождением в воздушное пространство Украины новых иностранных авиакомпаний, открытием новых воздушных линий украинских перевозчиками, одобрением безвизового режима со странами ЕС, модернизацией имеющейся инфраструктуры аэропортов и их развития с учетом современных требований. Представлены основные производственные показатели и проведен анализ пассажиропотока. Определено, что развитие гражданской авиации связано с общими тенденциями международного воздушного транспорта и обусловлен как общемировыми, так и внутригосударственными социально-экономическими, политическими и другими факторами. Определены основные направления деятельности отрасли на треть десятилетия 21 века.

Ключевые слова: гражданская авиация, авиакомпания, авиаперевозки, воздушное судно аэропорты, пассажиропоток, стратегия развития.

\section{Analysis of Current State of Air Transportation in Ukraine}

The tendencies of development of air transportation in Ukraine in the period of world globalization and liberalization in the air transportation market are considered. The analysis of domestic air transportation showed that the growth rate of air transportation in the Ukrainian segment of the market, despite the instability of the militarypolitical and economic situation in the country, is optimistic for predicting the future development of air transportation in Ukraine. The growth of the main indicators of the work of civil aviation in Ukraine demonstrates the growing interest of market participants in air transportation. The passenger air transportation market of Ukraine has sufficient prerequisites for its successful development. First of all, this is due to a significant increase in passenger transportation by air, the creation of new airlines in 
Ukraine, namely low-cost airlines, the entry of new foreign airlines into the airspace of Ukraine, the opening of new airlines by Ukrainian carriers, the approval of a visafree regime with EU countries, and the modernization of existing infrastructure airports and their development, taking into account modern requirements. The main production indicators are presented and passenger traffic analysis is carried out. It has been determined that the development of civil aviation is related to the general tendencies of international air transport and is conditioned by both global and national socio-economic, political and other factors. The main directions of the industry for a third of the decade of the 21st century are determined.

Key words: civil aviation, airline, air transportation, aircraft, airports, passenger traffic, development strategy.

\section{Відомості про авторів}

Орловський Михайло Миколайович - канд. техн. наук, доцент, доцент кафедри Проектування літаків та вертольотів, Національний аерокосмічний університет ім. М.Є. Жуковського «Харківський авіаційний університет», Харків, Україна. orl104@ukr.net . ORCID 0000-0003-3529-1816.

Приймак Андрій Володимирович - канд. техн. наук, доцент, доцент кафредри Проектування літаків та вертольотів, Національний аерокосмічний університет ім. М.Є. Жуковського «Харківський авіаційний університет», Харків, Україна. matrix 1971@ukr.net ORCID 0000-0002-4707-2429.

Хрістов Валерій Олексійович - старший викладач циклової комісії 3 конструкції та експлуатації літаків та двигунів ВКСС Харківського національного університету Повітряних Сил ім.І.Кожедуба, Харків, Україна. vkss2010@ukr.net ORCID 0000-0001-7508-5510

\section{About the Authors}

Orlovskyi Mykhailo - Ph.D, Associate Professor, Department of Airplanes and Helicopters Design, National Aerospace University, Kharkiv, Ukraine, e-mail: orl104@ukr.net. ORCID 0000-0003-3529-1816.

Priymak Andrey - Ph.D, Associate Professor, Department of Airplanes and Helicopters Design, National Aerospace University, Kharkiv, Ukraine, e-mail: matrix_1971@ukr.net. ORCID 0000-0002-4707-2429.

Khristov Valerii - Senior Lecturer Ivan Kozhedub Kharkiv National Air Force

University, Kharkiv, Ukraine, e-mail: vkss2010@ukr.net.
ORCID 0000-0001-7508-5510 